Our Nature (2004) 2:47-52

\title{
The Wetland Ecology
}

\author{
S.N. Jha \\ Tribhuvan University \\ Department of Botany \\ Post Graduate Campus, Biratnagar, Nepal \\ E-mail: sasinathjha@yahoo.com
}

Known as 'Simsar ( $\operatorname{sim}=$ low-grade land; sar = water)' in Nepali, wetlands are those areas which lie between the land and deepwater and remain waterlogged or submerged under water, seasonally or throughout the year. Generally the land is so muddy that one cannot easily walk over it, and the water is so deep that one can neither swim nor get drowned. River floodplains, shallow margins of lakes and reservoirs, shallow and seasonal ponds, islands in rivers, deepwater paddy fields, and seacoasts are typical examples of the wetlands.

Wetlands are essential for the free ecosystem services that they provide to the human community. The most obvious are maintenance or improvement of water quality, groundwater discharge and recharge, erosion control, soil building, food chain production, nutrient cycling and biogeochemical processes, habitat for wildlife, and numerous socioeconomic qualities such as food, forage, hunting and trapping, sites for research and environmental education, cultural heritage, open space preservation, aesthetics, tourism and recreation. They are also important because attention has been turned recently to using the wetland systems and the plant species occurring therein as bio-energy sources and also for use in pollution abatement projects to filter sewage, agricultural run-off, leachate from landfills, and acid mine drainage mitigation (Brooks 1989, Oliver and Hill 1998). It is the constellation of these and other functions and values that the wetlands are recognized as the 'kidneys of the landscape' or called as 'biological supermarkets'.

Unfortunately, the wetlands are being degraded today mainly due to pollution from sewage and industrial effluents, and from overexploitation of resources. The wetlands are rapidly disappearing because of the general notion that they are waterlogged and unproductive lands, which harbour diseasecarrying insects, pests and poisonous snakes. They are drained and/or filled for agriculture, human settlements and industries besides being rapidly silted due to large-scale deforestation in surrounding areas, and they are also being dried up in many places as rivers are dammed and channelized for the generation of hydroelectricity and other purposes.

\section{Wetland types}

Depending upon the nature of the dominant vegetation and the place of occurrence, the wetlands may be a marsh (dominated by herbaceous plants), swamp (dominated by shrubs and trees), mangrove (tidal areas with woody vegetation), or lagoon (coastal lakes connected with sea). Wetlands in Nepal are exclusively freshwater in nature. They occupy approximately $5 \%$ of the total area of the country mainly in the forms of rivers (395000ha/53\%), lakes (5000 ha/0.7\%), reservoirs (131 ha/0.2\%), village ponds 


\section{S.N. Jha / Our Nature (2004) 2:47-52}

(5183ha/0.7\%) paddy fields (325000 ha/ $43.6 \%)$, and marsh (12000ha/1.6\%) (HMG 1992). Though the country acceded to the convention of wetlands of international importance specially as waterfowl habitat (Ramsar Convention) on 17 December, 1987 at which Koshi Tappu was added to the list of wetlands of international importance, only those wetlands located within the National Parks/Wildlife Reserves are protected.

The high mountains of Nepal contain 16 glacial and 8 tectonic lakes, the famous ones being Panch Pokhari, Dig Tsho, Tonju, Gosain Kund, Bhairav Kund, Tilicho, Phoksundo and Rara. Among these, Rara (2990m altitude) is the largest (1036ha) and the deepest lake followed by Phoksundo. Limnological condition of the high mountain lakes is oligotrophic type as human distribution and disturbances and average annual temperature are less. The macrophytic vegetation, amphibians, birds and mammals do not occur in the glacial lakes, whereas dominant vegetation of the tectonic lakes are Myriophyllum in shallow water, and Phragmites (reeds). Juncus (rushes), Fimbristylis (sedges), etc. in the littoral zone. Notable faunal diversity of these lakes include sucker head (Garra spp.) and snow trouts (Schizothorax macrothalamus, S. nepalensis, $S$. rarensis) among the fishes; Himalayan toad (Bufo himalayensis) among the amphibians; common teal (Anas crecca) and mallard (A. platyrhynchos), bar-headed goose (Anser indicus), crested poachard (Aythya fuligula), and shelduck (Tadorna ferruginea) among the birds; and alpine mole (Apodemus flavicollis gurkha), smooth otter (Lutra perpicillata), Tibetan water shrew (Nectigale elegans), and Pitymus sikimensis among the mammals ( Loffler 1969, Ferro 1979, Scott 1989, Shrestha 1994).
The middle mountains of the country contain tectonic lakes (Phewa, Begnas, Rupa, Maidi, Dipong, Tity etc.) and riverine floodplains besides ponds, hydroelectricity reservoirs (Trishuli, Marshyangdi, Kule Khani), several pools and ponds and deepwater paddy fields. On the basis of productivity these wetlands are mesotrophic to eutrophic. The aquatic vegetation is richer than the high mountains and common wetland species are Ceratophyllum demersum, Eichhornia crassipes. Hydrilla verticillata, various species of Nymphaea and Nymphoides, Utricularia spp., Vallisneria natans, etc. Species diversity is highest in lentic bodies followed by slow moving lotic bodies away from dense human settlements. Copper ( Acrossocheilus hexagonalepis) and golden (Tor tor) mahaseer and mountain trout (Schizothorax richardsonii) among the fishes: various species of frogs ( Rana spp.) and newt (Tylotriton verrucosus) among the amphibians; common teal and mallard, pintail (Anas acuta), pond heron (Ardleola greyii), cattle egret (Balbulcus ibis), pied king fisher (Ceryle rudis), coot (Fulica atra), common snipe (Gallinago gallinago), bronze winged Jacana (Metopidius indicus), and purple moorhen (Porphyrio prophyrio) among birds; and small clawed otter (Anonyx cincrea), smooth otter, and fishing cat (Felis viverrino) among the mammals constitute the notable faunal diversity associated with the wetlands of the middle mountains (Joshi 1973, Rajbhandari 1982, East Consultant 1990).

Wetlands of the Terai plain include extensive floodplains of the rivers Koshi, Gandaki (Narayani), Karnali and Mahakali, marshlands, several ox-bow lakes, paddy fields, etc. and these are mesotrophic to eutrophic in productivity. Common floating plants of this 


\section{S.N. Jha / Our Nature (2004) 2:47-52}

region are Azolla imbricata, Eichhornia crassipes, Lemna minor, Pistia stratiotes, and Spirodela polyrhiza; the submerged species are Ceratophyllum demersum, Chara canescens, Hydrilla verticillata, Potamogeton crispus and Utricularia aurea; the floating-leafed species are Euryale ferox, Ludwigia adscendens, Nelumbo nucifera, Nymphaea pubescens, Nymphoides hydrophyllum and Trapa quadrispinosa; whereas common emergent species are Alternanthera philoxeroides, Certopteris thalictroides, Hygrophila auriculata, Marsilea crenata, Oryza rufipogon, Sagittaria trifolia, Schoenoplectus grossus and Typha angustifolia. Common fishes of these wetlands include pothi (Amblypharyngodon mola), anhai (Amphipnous cuchia), garai (Channa punctatus) and saura (C. striatus), naini (Cirrhinus mrigala), mungur (Clarius batrachus), singhi (Heteropneustes fossilis), rohu (Labeo rohita), bami (Mastacembelus pancalus), tengra (Mystus seeghala), and buari (Wallago attu). Bull-frog (Rana tigrina) is the common amphibian, whereas notable herpetofauna include muggar (Crocodylus palustris), smooth water snake (Enhydris enhydris), gharial (Gavialis gangeticus) and turtle (Lissemys punctatus). Majority of the avian fauna ( $>60 \%$ ) of Nepal including different species of kingfisher (Alcedo atthis, A. menintin, Halcyon symrnensis, Pelargopsis capensis), pied hornbill ( Anthracoceros malabaricus), paddy-field pipit (Anthus novaeseelandae), golden eagle (Aquila chrysactos), pond heron (Ardea purpurea) saras crane (Grus antigone antigone), cattle egret, common teal, pintail, mallard, coot, and grey hornbill (Tockus birostris) inhabit the terai wetlands. Notable mammals of these wetlands are wild water buffalo (Bubalus bubalis), smooth otter, fishing cat, and Gangetic dolphin (Platanista gangetica).

In 1995, Biodiversity Profile Project (BPP/ HMG) made rapid assessment of status of wetlands in the terai plain. It explored 51 sites out of which 36 were found to be of sufficient biodiversity importance including Bishazaretal (area 180ha) of Gitanagar (Chitwan), Gaindahawa (11 ha) of Bishnupur (Rupendehi), Jagdishpur reservoir (150ha) of Niglihawa (Kaplivastu), Badhaiya (100ha) of Chailahi (Bardiya). Ghodaghodi-tal (150ha) of Darkhnidi (Kailali), Narerodi-tal (100 ha) of Sandepani (Kailali), Rampur-tal (20ha) of Urma (Kailali), Deukhuria (22ha) of Dhangarhi municipality (Kailali), Pitriyani (35ha) of Krishnapur (Kanchanpur) and Betkot (4 ha) of Daiji (Kanchanpur). These wetlands harbour rare wildlife including native and migratory birds and also function as wildlife corridors. For example, Ghodaghodi-tal is an important transient site for migratory species migrating between Dudhwa (Corbett) National Park (India), Royal Suklaphanta Wildlife reserve and Royal Bardiya National Park. Further, these wetlands are surrounded by several villages whose economy is intimately lined with the use and exploitation of wetland resources (Bhatt and Shrestha 1973, Dinerstein 1979a, Dinerstein 1979b, Inskipp and Inskipp 1985, Scott 1989, Bauer et al. 1994, Jha 2003).

\section{Physico-chemical properties}

In high altitude lakes of Nepal, Loffler (1969) reported the dominance of calcium among cations, low chloride and less than $1 \mu \mathrm{g} /$ 1 phosphorus. Aizaki et al. (1987 reported $<6$ $\mu \mathrm{g} / 1$ phosphorus in the lake Tilito and considered this level to be limiting to the lake productivity. Similarly, James and Hubbick (1969) found the low level of nitrogen as 


\section{S.N. Jha / Our Nature (2004) 2:47-52}

limiting factor in the high altitude lakes of Nepal. According to McEachern (1994), light and temperature are the most predominate limiting factors for the lake productivity at high altitudes.

In highland $(>2000 \mathrm{~m})$ rivers of Nepal, Ormerod et al. (1996) reported the $\mathrm{pH}$ range between 7.3 to $8,0.4$ to $1.4 \mathrm{mg} / 1$ chloride, 0.06 to $0.28 \mathrm{mg} / 1$ nitrate, and 0.02 to $0.04 \mathrm{mg} / 1$ phosphate. Dangol and Lacoul (1996) reported 6.9 to $7.2 \mathrm{pH}, 0.15$ to $0.38 \mathrm{mg} / 1$ nitrate, 0.22 to $0.62 \mathrm{mg} / 1$ phosphate, and 6.0 to $7.3 \mathrm{mg} / 1$ dissolved oxygen in the midland $(1000-2000 \mathrm{~m})$ rivers of Nepal. McEachern (1994) reported $8.4 \mathrm{pH}, 0.23 \mathrm{mg} / 1$ phosphate, and $8.5 \mathrm{mg} / 1$ dissolved oxygen in Narayani, a lowland $(<1000 m)$ river of Nepal. Sharma (1996) studied the various physico-chemical properties of the Koshi river water and found it to be clean with healthy and productive environment for its biotic components on the basis of annual averages of conductivity $(211 \mu \mathrm{s}$ $/ \mathrm{cm}), \mathrm{pH}$ (slightly alkaline), free $\mathrm{CO}_{2}(5 \mathrm{ppm})$, dissolved oxygen $(6.6 \mathrm{ppm})$, total alkalinity (50ppm), fluoride(19.5ppm), and the magnitude of ionic composition in the order: $\mathrm{Ca}(34 \mathrm{ppm})>$ $\mathrm{C} 1$ (23.8ppm) $>\mathrm{Na}(5.3 \mathrm{ppm})>\mathrm{NO}_{3} \quad(2.4 \mathrm{ppm})$ $>\mathrm{Mg}(1.9 \mathrm{ppm})>\mathrm{K}(0.9 \mathrm{ppm})>\mathrm{O}_{4}(0.15 \mathrm{ppm})$.

\section{Wetland macrophytes}

Seasonally, the macrophytic communities change considerably in tropical wetlands of the Indo-Gangetic plain (Rai and Sharma 1991). Drying of water in seasonally flooded areas during summer exposes the substrate and allows the germination of burried seeds of perennial emergent and annual mud-flat plants. After the arrival of monsoon, standing water returns and the mud-flat species disappear leaving only the emergent. The submerged species quickly reappear as their seeds readily germinate in standing water. The emergents increase in density and become dominant during the monsoon season, but with the decline of water level in October-November this community starts senescing. During winter, emergent have maximum biomass, carbohydrates and nutrients belowground particularly in rhizomes, and after the arrival of summer, there is a burst of shoot growth, which is fueled by photosynthesis and translocation of carbohydrates and other nutrients stored in their rhizomes (Bernard 1998).

Rai (1980) has reported that the percent frequency of bottom-rooted floating leafed species attains the highest value in monsoon and lowest in winter, whereas the submerged species have the highest frequency in winter and lowest in monsoon in permanent wetlands of north Bihar (India).

Ambasht (1971) in a ecosystem analysis of a small pond in the Banaras Hindu University Campus (India) found highest density of 3400 plants $/ \mathrm{m}^{2}$ for small free floating Azolla pinnata to about 200 plants/ $\mathrm{m}^{2}$ in emergent zone of Eleocharis plantaginea. This pond, free from any pollution, had $2.21 \mathrm{~kg} /$ $\mathrm{m}^{2}$ dry biomass in shallow zone with emergent vegetation, and $0.57 \mathrm{~kg} / \mathrm{m}^{2}$ in floating leafed Trapa bispinosa central zone. Energy concentration was highest in Eleocharis $(3568 \mathrm{cal} / \mathrm{g})$ followed by Trapa $(2883 \mathrm{cal} / \mathrm{g})$, and least in Azolla (2183cal/g).

In Ramgarh wetland of Gorakhpur (India), Sinha (1969) calculated $930 \mathrm{~g} / \mathrm{m}^{2} / \mathrm{yr}$ production in emergent zone, and a little over $100 \mathrm{~g} / \mathrm{m}^{2} / \mathrm{yr}$ in floating and submerged zones. In temperate climate of Srinagar (Kashmir, India), Kaul (1971) found $2800 \mathrm{~g} / \mathrm{m}^{2} / \mathrm{yr}$ productivity in the emergent, and $880 \mathrm{~g} / \mathrm{m}^{2} / \mathrm{yr}$ in floating zone of the Dal Lake.

In many areas throughout the world flooding commonly occurs and have adverse 


\section{S.N. Jha / Our Nature (2004) 2:47-52}

effects on terrestrial plant growth and development. Therefore information gained by better understanding of process occurring in wetlands could be used to better manage them and to provide additional benefits to solve other ecological and agricultural problems.

\section{References}

Aizakim, M., A. Terashima, H. Nakahara, T.Nisho and Y Ishida 1987. Trophic status of Tilito, a high altitude Himalayan lake. Hydrobiologia 153:217-224.

Ambasht, R.S.1971. Ecosystem study of a tropical pond in relation to primary production of different vegetation zones. Hydrobiologia 12: 57-61.

Bauer, J.J., T. Maskey and G. Raut 1994. River systems, hydro development and the species crisis in terai. In: B. Bhandari, T.B. Shrestha and McEachern (eds.) Safeguarding Wetlands in Nepal. IUCN, Nepal. pp: 1-19.

Bernard, J.M. 1998. Population biology of wetland plants. In: S.K. Majumdar, E.W. Miller and F.J. Brenner (eds.) Ecology of Wetlands and Associated Systems. The Pennsylvania Academy of Science, Easton, PA. pp:228-239.

Bhatt, D.D. and T.K. Shrestha 1973. The Environment of Suklaphanta. Curriculum Development Centre, Tribhuvan University, Kathmandu.

Biodiversity Profiles Project 1995. The biodiversity Importance of Nepal. Department of National Parks and Wildlife Conservation, His Majesty's Government, Katmandu, Nepal.

Brooks, R.P. 1989. An overview of ecological functions and economic values of wetlands. In: S.K. Majumdar, R.P. Brooks, F.J. Brenner and R.W. Tiner (eds.)Wetland Ecology and Conservation : Emphasis in Pennsylvania. The Pennsylvania Academy of Science, Easton, PA. p.395.

Dangol, N.S. and P. Lacoul 1996. Growth and clump maintenance of Potamogeton crispus L., in Punyamati river, Panauti, Nepal, In: P.K. Jha,
G.P.S.Ghimire, S.B. Karmacharya, S.R. Baral and P. Lacoul (eds.) Environment and Biodiversity; In the context of South Asia. Ecological Society (ECOS), Kathmandu. pp:141-147.

Dinerstein, E. 1979a. An ecological survey of the Royal Karnali-Bardiya Wildlife Reserve, Nepal. Part I. Vegetation, modifying factors and successional relationships. Biological Conservation 15: 127-150.

Dinerstein, E.1979b. An ecological survey of the Royal Karnali-Bardiya Wildlife Reserve, Nepal. Part II. Habitat/ animal interactions. Biological Conservation 16:265-300.

East Consultant 1990. Environmental Impact Study of Drinking Water supply in Kathmandu and Lalitpur from outside the valley, Kathmandu. Report, East Consultant, Kathmandu.

Ferro, W. 1979. Some Limnological and biological data from lake Rara, a deep Himalayan lakes in Nepal. Journal of the Nepal Research Centre 2(3): 241-261.

HMG (His Majesty's Government, Nepal) 1982. National Fisheries Development Plan, 199293. Fisheries Development Division, Department of Agriculture Development, Kathmandu.

Inskipp, C.and T. Inskipp 1985. A guide to the Birds of Nepal. Croom Helm, Beckenham.

James, A. and J. Hubbick 1969. Studies on some high altitude lakes in the Hindukush Himalays. Verh International Verein Limnology 17 :362372.

Jha, S. 2003. Ecological study of some selected grasses and forbs found in Morang district of Nepal. Ph. D. Thesis, Tribhuvan University, Kathmandu.

Joshi, S.D. 1973. Dominant Aquatic angiosperms in Taudah. Journal of Science (Nepal) 5 (1): 14-17.

Kaul, V. 1971. Production and ecology of some macrophytes of Kashmir lakes. Hydrobiologia 12:63-69.

Loffler, H. 1969. High altitude lakes in the Mt. Everest region. Verh International Verein Limnology 17:373-385 


\section{S.N. Jha / Our Nature (2004) 2:47-52}

McEachern, P. 1994. Limnology and the natural wetlands survey. In : B. Bhandari, T.B. Shrestha and P.McEachern (eds.) Safeguarding Wetlands in Nepal. IUCN, Nepal. pp: 89-103.

Oliver III, J.C. and R.J. Hill 1998. Foreword. In : S.K. Majumdar E.W. Miller and F.J. Brenner (eds.) Ecology of wetlands and Associated Systems. The Pennsylvania Academy of Science, Easton, PA.pp: I-III.

Ormerod, S.J., S.T. Buckton, P.A. Brewin, A. Jenkins, R.C. Johnson, U. Juttner and A. Suren 1996. Biodiversity, Chemistry and structure in streams of the Nepalese Himalya. In :S.R. Chalise and N.R. Khanal (eds.) Proceedings International Conference on Ecohydrology of High Mountain Areas. ICIMOD, Kathmandu. pp:197-200.

Rai, D.N. 1980. Ecological structure of certain swamps of Darbhanga (Bihar). Ph.D. Thesis, Bhagalpur University, Bhagalpur.

Rai, D.N. and U.K. Sharma 1991. Phytocoenol ogical structure and classification of wetlands in north Bihar. In: B. Gopal and V. Ashana (eds.)
Aquatic Sciences In India. Indian Association for Limology and Oceanography, New Delhi, pp: 111-116.

Rajbhandari, S.1982. Floristic study and distribution of aquatic angiosperms in Kathmandu Valley. M Sc. Dissertation, Central Department of Botany, Tribhuvan Universtiy, Kathmandu.

Scott, D.A. (ed.) 1989. A Dirctory of Asian Wetlands. IUCN. Gland and Cambridge.

Sharma, U.P.1996. Ecology of the Koshi river in Nepal-India (north Bihar): a typical river ecosystem. In : P.K. Jha, G.P.S. Ghimire, S.B. Karmacharya, S.R. Baral and P. Lacoul (eds.) Environment and Biodiversity: In the context of south Asia. Ecological Society, Kathma ndu.pp: 92-99.

Shrestha, T.K. 1994. Wetland fauna in Nepal. In: B.Bhandari, T.B.Shrestha and P. McEachern (eds.) Safeguarding Wetlands in Nepal. IUCN, Nepal, pp: 41-52.

Sinha, A.B.1969. Investigation on the ecology of Ramgarh lake. Ph.D Thesis, Gorakhpur University, Gorakhpur. 